\title{
EVALUATION OF SERUM PROCALCITONIN, SERUM IRON AND RE.D CELL DISTRIBUTION WIDTH (RDW) AS NOVEL BIOLOGICAL MARKERS IN INFLAMMATORY BOWEL DISEASES.
}

\author{
Dina Fathy. M*, Waleed Hamed*, Zeinab M Hefny*, Shimaa Youssef*, Marwa M \\ Shakweer**, Doaa. M. A***
}

\author{
*Tropical Medicine, \\ **Pathology and ***Clinical \\ Pathology Departments Ain \\ Shams University. \\ Cairo, Egypt. \\ .Corresponding : \\ Dina Fathy.M \\ Mobile: 01063196110 \\ E mail: \\ drdeenaibrahim@gmail.com.
}

Received: 15/5/2019

Accepted: 11/6/2019

\begin{abstract}
:
Background: Ulcerative colitis and Crohn's disease are idiopathic inflammatory bowel diseases (IBD). Although some clinical activity indexes are commonly used in IBD, specific and sensitive laboratory markers that correlate with disease activity and associated complication are still lacking. Traditional markers, such as $C$-reactive protein (CRP), the erythrocyte sedimentation rate (ESR), and the white blood cell (WBC) count, are still the most common markers used in clinical practice. Procalcitonin (PCT) plays a major role in systemic inflammation and induces a dose-dependent increase in $T N F \alpha$ secretion. Plasma level of PCT increases during bacterial infections and sepsis. There are some data showing that serum PCT level is a useful marker in many inflammatory disorders. Previous findings suggested that inflammatory and infectious disease of the bowel might increase serum PCT levels. Anemia is the most prevalent extra intestinal complication of IBD. Serum iron was previously included in several studies as inflammatory marker of IBD.RDW is a quantitative measurement of anisocytosis. Pro-inflammatory cytokines have been reported to inhibit the maturation of erythrocytes, which is caused by erythropoietin. Thus, inflammation causes immature red blood cells to be released into the peripheral circulation, which may result in anisocytosis.
\end{abstract}

Aim of the work: This study aims to evaluate sensitivity and specificity of serum procalcitonin, serum iron and red cell distribution width $(R D W)$ as novel biological markers of activity in IBD patients.

Patients and methods: 60 Patients with confirmed IBD diagnosis (Crohn's and ulcerative colitis) were divided into 2groups (30 remission and 30 exacerbation) classified according to Truelove and Witts index in ulcerative colitis and Harvey Bradshaw index in Crohn's disease. Routine diagnostic investigations, serum Procalcitonin and serum iron level were withdrawn. Serum procalcitonin was done by commercially available ELISA kits.

Results: The study showed significant difference between the 2 groups as regards serum iron where median in remission was 52 $\mathrm{mcg} / \mathrm{dl}$ while in activity was $26 \mathrm{mcg} / \mathrm{dl}$ ( $P$ value:0.033), also for $R D W$ $(P$ value:0.014) and serum procalcitonin where mean in remission was $0.62 \mathrm{ng} / \mathrm{ml}$ while in activity was $0.98 \mathrm{ng} / \mathrm{ml}$ ( $P$ value:0.029).

Conclusion: $R D W$, serum procalcitonin and serum iron in $I B D$ patients need to be included in further studies with larger sample size for the possibility to be used as future laboratory markers for disease activity. 
Keywords: inflammatory bowel disease, ulcerative colitis, Crohn's disease, red cell distribution width, serum procalcitonin, serum iron.

Abbreviations: TNF: Tumor necrotic Factor.

\section{INTRODUCTION:}

Ulcerative colitis (UC) and Crohn's disease (CD) are idiopathic inflammatory bowel diseases that are generally complicated by systemic or local infection. Clinical, endoscopic, histological, and radiological investigations are typically necessary to make an accurate diagnosis and assessment of disease activity ${ }^{(1)}$.

Although some clinical activity indexes are commonly used in IBD, specific and sensitive laboratory markers that correlate with disease activity and associated complication are still lacking ${ }^{(2)}$.

Traditional markers, such as C-reactive protein (CRP), the erythrocyte sedimentation rate (ESR), and the white blood cell (WBC) count, are still the most common markers used in clinical practice ${ }^{(3)}$.

C-reactive protein (CRP) is a widely used marker of inflammation and it has been shown to correlate with disease activity, especially in CD patients (4). It increases rapidly during inflammatory processes and resolves early after amelioration of the inflammation. However, in UC patients, CRP response is usually moderate ${ }^{(5)}$.

Procalcitonin, a prohormone of 116 amino acids is the precursor for the calcium homoeostasis hormone, calcitonin, which is found in the thyroid $\mathrm{C}$ cells and the pulmonary endocrine cells. It has been found to circulate at very low concentrations in normal serum ${ }^{(6)}$.

Procalcitonin plays a major role in systemic inflammation and induces a dosedependent increase in TNF $\alpha$ secretion ${ }^{(7)}$.

Plasma level of PCT increases during bacterial infections and sepsis ${ }^{(8)}$. There are some data showing that serum PCT level is a useful marker in many inflammatory disorders. A previous study showed that plasma concentrations of PCT appear to reflect the derangement in gut barrier function in patients with acute pancreatitis ${ }^{(9)}$.Similarly, another one showed that serum PCT levels increase significantly after colorectal surgery ${ }^{(10)}$. Those findings suggested that inflammatory and infectious disease of the bowel might increase serum PCT levels ${ }^{(11)}$.

In patients with inflammatory bowel diseases (IBD), the association of procalcitonin with disease activity remains poorly investigated ${ }^{(12)}$.

Anemia is the most prevalent extra intestinal complication of IBD and can substantially affect the quality of life of patients with $\operatorname{IBD}^{(13)}$.

Serum iron was previously included in a number of study as inflammatory marker of IBD.

RDW is a quantitative measurement of anisocytosis. Pro-inflammatory cytokines have been reported to inhibit the maturation of erythrocytes, which is caused by erythropoietin. Thus, inflammation causes immature red blood cells to be released into the peripheral circulation, which may result in anisocytosis ${ }^{(14)}$.

\section{AIM OF THE WORK:}

This study aims to evaluate sensitivity and specificity of serum procalcitonin, serum iron and red cell distribution width (RDW) as novel biological markers of activity in IBD patients. 


\section{PATIENTS AND METHODS:}

This is a case control study where 60 Patients with confirmed IBD (Crohn's and ulcerative colitis) were divided into group A: which included 30 patients with IBD in remission (controls) and group B 30 patients with IBD in activity (cases) classified according to Truelove and Witt's index in ulcerative colitis and Harvey Bradshaw index in Crohn's disease.The diagnosis of IBD was confirmed by a typical history, appropriate endoscopic and radiologic imaging studies as well as histopathological evaluations.
All patients were subjected to clinical evaluation and investigation workup: Complete history taking and thorough clinical examination, laboratory investigations: CBC with RDW,ESR, CRP, serum albumin, stool analysis. In addition to the routine diagnostic investigations, serum Procalcitonin and serum iron level were withdrawn. Serum procalcitonin was done by commercially available ELISA kits.

Ulcerative colitis patients were categorised into mild, moderate and severe based on the Truelove and Witts' severity index (3).

\begin{tabular}{llll}
\hline Feature & Mild & Moderate & Severe \\
\hline Motions per day & $<4$ & $4-6$ & $>6$ \\
\hline Rectal bleeding & Little & Moderate & Large amounts \\
\hline Temperature & Apyrexial & Intermediate & $\begin{array}{l}>37.8^{\circ} \mathrm{C} \text { on } \\
2 \text { of } 4 \text { days }\end{array}$ \\
\hline Pulse rate & Normal & Intermediate & $>90 \mathrm{bpm}$ \\
\hline Haemoglobin & Normal & Intermediate & $<10.5 \mathrm{~g} / \mathrm{dL}$ \\
\hline ESR & Normal & Intermediate & $>30 \mathrm{~mm} / \mathrm{h}$ \\
\hline ESR, erythrocyte sedimentation rate. & & \\
\hline
\end{tabular}

Crohn's disease patients were classified according to Harvey Bradshaw index:

The Harvey-Bradshaw index was devised in 1980 as a simpler version of the CDAI for data collection purposes. It consists of only clinical parameters:

\begin{tabular}{|l|l|}
\hline General well being & $0=$ =ery well \\
& $1=$ slightly below average \\
& $2=$ =oor \\
& $3=$ very poor \\
& $4=$ terrible \\
\hline Abdominal pain & $0=$ none \\
& $1=$ mild \\
& $2=$ moderate \\
& $3=$ severe \\
\hline Number of liquid stool per day \\
\hline Abdominal mass & $0=$ none \\
& $1=$ dubious \\
& $2=$ definite \\
& $3=$ tender \\
\hline Complications: with one & $\begin{array}{l}\text { Arthralgia, uveitis, erythemanodosum,a phtousulcer, } \\
\text { point for each }\end{array}$ \\
\hline
\end{tabular}

A score of less than 5 is generally considered to represent clinical remission ${ }^{(15)}$. 


\section{Data Management and Analysis:}

The collected data was revised, coded, tabulated and introduced to a PC using Statistical package for Social Science (SPSS 20). Data was presented and suitable analysis was done according to the type of data obtained for each parameter.

\section{i. Descriptive statistics:}

1. Mean, Standard deviation $( \pm \mathrm{SD})$ and range for parametric numerical data, while Median and Interquartile range (IQR) for non parametric numerical data.

2. Frequency and percentage of nonnumerical data.

\section{ii. Analytical statistics:}

1. Student T Test was used to assess the statistical significance of the difference between two study group means.

Table 1: Smoking and presentation in IBD patients

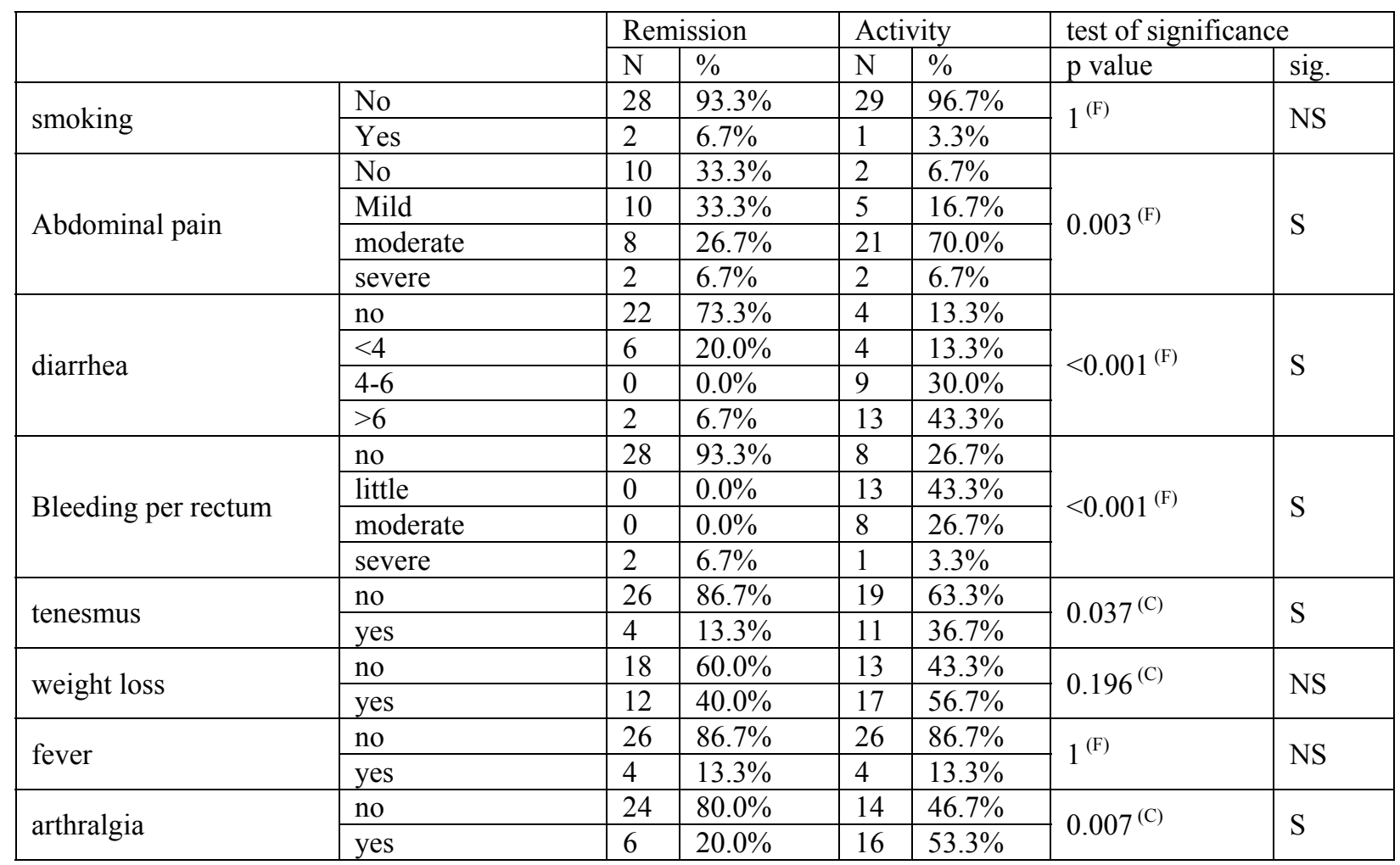

2. Mann Whitney Test (U test) was used to assess the statistical significance of the difference of a non parametric variable between two study groups.

3. Chi-Square test was used to examine the relationship between two qualitative variables

4. Fisher's exact test: was used to examine the relationship between two qualitative variables when the expected count is less than 5 in more than $20 \%$ of cells

Measurement the serum level of high sensitive CRP was done by using ELISA enzyme linked immunosorbent assay (Bio check, Inc, 323Vinlage park Drive Foster city, CA 94404).

Serum Procalcitonin was done also by sandwich ELISA.

Serum Iron was done by using AU 680 chemistry Beckman Coulter auto-analyzer.

\section{RESULTS:}


Evaluation Of Serum Procalcitonin, Serum Iron And Re.D Cell Distribution Width (Rdw) As Novel..

\begin{tabular}{|c|c|c|c|c|c|c|c|}
\hline \multirow{2}{*}{ aphthos ulcer } & no & 30 & $100.0 \%$ & 25 & $83.3 \%$ & \multirow{2}{*}{$0.052^{(\mathrm{F})}$} & \multirow{2}{*}{ NS } \\
\hline & yes & 0 & $0.0 \%$ & 5 & $16.7 \%$ & & \\
\hline \multirow{2}{*}{ eye } & no & 30 & $100.0 \%$ & 28 & $93.3 \%$ & \multirow{2}{*}{$0.492^{(\mathrm{F})}$} & \multirow{2}{*}{ NS } \\
\hline & yes & 0 & $0.0 \%$ & 2 & $6.7 \%$ & & \\
\hline \multirow{2}{*}{ pyoderma gangrenosa } & no & 30 & $100.0 \%$ & 28 & $93.3 \%$ & \multirow{2}{*}{$0.492^{(\mathrm{F})}$} & \multirow{2}{*}{ NS } \\
\hline & yes & 0 & $0.0 \%$ & 2 & $6.7 \%$ & & \\
\hline \multirow{2}{*}{ Abdominal mass } & no & 28 & $93.3 \%$ & 29 & $96.7 \%$ & \multirow{2}{*}{$1^{(\mathrm{F})}$} & \multirow{2}{*}{ NS } \\
\hline & yes & 2 & $6.7 \%$ & 1 & $3.3 \%$ & & \\
\hline
\end{tabular}

$\mathrm{F}:$ Fisher exact test

C: Chi square test

There is no statistically significant difference between patients in remission and in exacerbation as regards smoking.

This table shows that there is statistically significant difference between the two groups as regards abdominal pain where $76.7 \%$ of patients in activity have moderate to severe pain in comparison to $33.4 \%$ of patients in remission.

There is significant difference in diarrhea where $73.3 \%$ of patients in remission have no diarrhea in contrast to patients in activity where $13.3 \%$ have less than 4 motions(mild),30\% have 4-6 motions(moderate) and $43.3 \%$ have $>6$ motions(severe).

There is significant difference in bleeding per rectum where $6.7 \%$ of patients in remission have bleeding per rectum in contrast to patients in activity where $73.3 \%$ have bleeding per rectum.

There is significant difference in ten esmus where $13.3 \%$ of patients in remission have ten esmus in comparison to $36.7 \%$ in activity.

There is significant difference as regards arthralgia where $80 \%$ of patients in remission have no arthralgia while 53.3\% during activity.

There is no significant difference between patients in remission and activity as regards fever, weight loss, history of abdominal mass and other extra intestinal manifestation.

Table 2: Comparison of clinical examination between patients in remission and activity

\begin{tabular}{|c|c|c|c|c|c|c|c|}
\hline & \multicolumn{2}{|c|}{ Remission } & \multicolumn{2}{|c|}{ Activity } & \multicolumn{2}{|c|}{ test of significance } \\
\hline & & $\mathrm{N} /$ Mean & $\% / \mathrm{SD}$ & $\mathrm{N} /$ Mean & $\% / \mathrm{SD}$ & $p$ value & sig. \\
\hline \multirow{2}{*}{ Pulse } & normal & 28 & $93.3 \%$ & 22 & $73.3 \%$ & \multirow{2}{*}{$0.038^{(\mathrm{C})}$} & \multirow[b]{2}{*}{ S } \\
\hline & $>90$ & 2 & $6.7 \%$ & 8 & $26.7 \%$ & & \\
\hline \multirow{2}{*}{ Fever } & $<37.5$ & 30 & $100.0 \%$ & 29 & $96.7 \%$ & \multirow{2}{*}{$1^{(\mathrm{F})}$} & \multirow{2}{*}{ NS } \\
\hline & $>37.5$ & 0 & $0.0 \%$ & 1 & $3.3 \%$ & & \\
\hline abd. mass & no & 30 & $100.0 \%$ & 30 & $100.0 \%$ & & \\
\hline
\end{tabular}
F : Fisher exact test
$\mathrm{C}$ : Chi square test
$\mathrm{T}: \mathrm{t}$ test

This table shows that there is a significant difference between the 2 groups as regards pulse

Where $93.3 \%$ of patients in remission have normal pulse and $6.7 \%$ only have

tachycardia $>90$ while $73.3 \%$ in activity have normal pulse and $26.7 \%$ have pulse $>90$.

There is no significant difference in fever between the 2 groups. 
Dina Fathy. M., et al.,

Table 3: Comparison of RDW, CRP, serum iron and serum procalcitonin in remission and activity

\begin{tabular}{|l|c|c|c|c|c|c|}
\hline & \multicolumn{2}{|c|}{ Remission } & \multicolumn{2}{c|}{ Activity } & \multicolumn{2}{c|}{ test of significance } \\
\cline { 2 - 7 } & Mean / Median & SD / IQR & Mean / Median & SD / IQR & p value & sig. \\
\hline RDW & 14.09 & 1.18 & 15.78 & 3.38 & $0.014^{(\mathrm{T})}$ & $\mathrm{S}$ \\
\hline CRP & 5 & $3.2-10$ & 8.25 & $3.5-25$ & $0.176^{(\mathrm{M})}$ & $\mathrm{NS}$ \\
\hline S.Iron (mcg/dl) & 52 & $30-68$ & 26 & $12-60$ & $0.033^{(\mathrm{M})}$ & $\mathrm{S}$ \\
\hline Procal $(\mathrm{ng} / \mathrm{ml})$ & 0.62 & 0.44 & 0.98 & 0.76 & $0.029^{(\mathrm{T})}$ & $\mathrm{S}$ \\
\hline
\end{tabular}

T: $t$ test M: Mann Whitney test

This table shows significant difference between the 2 groups in serum iron where median in remission is $52 \mathrm{mcg} / \mathrm{dl}$ while median in activity is $26 \mathrm{mcg} / \mathrm{dl}$.

There is significant difference in serum procalcitonin where mean in remission is $0.62 \mathrm{ng} / \mathrm{ml}$ while in activity is $0.98 \mathrm{ng} / \mathrm{ml}$.

There is no significant difference between the 2 groups as regards CRP.

\section{DISCUSSION:}

In our study, we did not find any correlation between smoking habits and the occurrence or severity of IBD ( $P$ value $=1)$ because most of our patients in this study did not have a history of smoking at the time of diagnosis. There is no statistically significant difference between patients in remission and in exacerbation as regards smoking, this was similar to the study conducted by (Esmat et al. ${ }^{(16)}$ where they did not find any correlation between smoking habits and the occurrence or severity of UC because most of their patients did not have a history of smoking at the time of diagnosis.

As regards disease presentation in the 2 study groups, patients in activity have more significant difference in the occurrence of abdominal pain $(\mathrm{P}=0.003)$, diarrhea $(\mathrm{P}$ $<0.001)$, bleeding per rectum $(\mathrm{P}<0.001)$, tenesmus $(\mathrm{P}=0.037)$ and tachycardia $(\mathrm{P}=$ 0.038 ) than patients in remission, those symptoms can be declared as clinical indices of severity for IBD. The cardinal symptom of UC is bloody diarrhea, sometimes accompanied with abdominal pain or frequent bowel movements. The cardinal symptoms of CD are similar to UC. Patients frequently present with chronic abdominal pain and/or diarrhea ${ }^{(17)}$.

As regards extra intestinal manifestations the occurrence of arthralgia was more significant in the activity group $(\mathrm{P}=0.007)$ while occurrence of other extra intestinal manifestation wasn't significantly different between both groups. Joint involvement is the most common extra intestinal manifestation in IBD, affecting up to $35 \%$ of patients ${ }^{(18)}$.

Our study found that the mean value for RDW in remission is $14.09 \%$ while in exacerbation is $15.78 \%$ and that there is a significant difference between the 2 groups ( $\mathrm{P}$ value 0.014), this is similar to the study by Ipek et al. ${ }^{(19)}$ who conducted his study on 310 ulcerative colitis patients and found that the mean RDW levels in patients with active ulcerative colitis and in those in remission were $16.8 \pm 2.9$ and $15.5 \pm 1.4$, respectively $(\mathrm{P}<0.001)$.

As regards CRP, we found that there is no significant difference between the 2 groups as regards CRP (P value 0.176), in contrast to Ipek et al., ${ }^{(19)}$ who found that CRP levels were significantly increased in patients with active UC compared to the patients in remission ( $\mathrm{P}$ value $<0.001$ ). There is remarkable heterogeneity in the CRP response between $\mathrm{CD}$ and UC. Whereas CD is associated with a strong CRP response, UC has only a modest to absent CRP response ${ }^{(20)}$.

Also, we concluded that the serum procalcitonin level was higher in patients with IBD activity of a mean of $0.98 \mathrm{ng} / \mathrm{ml}$ than those in remission with a mean of 0.62 
$\mathrm{ng} / \mathrm{ml}$ (P value 0.029). This was similar to a study by Oussalah et al., ${ }^{(12)}$ that showed that the median value of serum procalcitonin was significantly higher in patients with active IBD $(0.1 \mathrm{ng} / \mathrm{mL}$; IQR $25-75$ th, 0.07 to 0.21$)$ in comparison with those with inactive disease $(0.07 \mathrm{ng} / \mathrm{ml}$; IQR $25-75$ th, 0.06 to 0.08) $(\mathrm{P}=0.02)$. Similarly, Koido et al., ${ }^{(21)}$, showed that PCT was $\sim 3$-fold higher in patients with active disease Nishio et al. ${ }^{(22)}$ found that PCT was $\sim 3$-fold higher in patients with active disease but not in those with active UC. In contrast Chung et al., ${ }^{(23)}$ Ge et al., ${ }^{(24)}$ and Hosomi et al., ${ }^{(25)}$ found that PCT was non-significantly higher in patients with active disease

While studying serum iron in IBD patients we found that there is a significant difference between the 2 groups ( $\mathrm{P}$ value 0.033 ).

\section{REFERENCES:}

1. Bruining DH, Loftus EV. Evolving diagnostic strategies for inflammatory bowel disease (2006). Curr Gastroenterol Rep; 8: 478-485.

2. Papp M, Norman GL, Altorjay I, Lakatos PL. Utility of serological markers in inflammatory bowel diseases: gadget or magic?. World J Gastroenterol (2007); 13: 2028-36.

3. D'Haens G, Sandborn WJ, Feagan BG. A review of activity indices and efficacy end points for clinical trials of medical therapy in adults with ulcerative colitis. Gastroenterology (2007); 132: 763-786.

4. Desai D, Faubion WA, Sandborn WJ. Biological activity markers in inflammatory bowel disease. Aliment PharmacolTher (2007); 25: 247-55.

5. Gabay C, Kushner I. Acute-phase proteins and other systemic responses to inflammation. N Engl J Med (1999); 340: 448-54

6. Becker KL, Snider R, Nylen ES. Procalcitonin in sepsis and systemic inflammation: a harmful biomarker and a therapeutic target. Br J Pharmacol (2010); 159: 253-264 .

7. AP, Gibbs KW, Yoon B et al., Human leukocyte and whole blood cytokine response to exogenous procalcitonin. (2007) The 89th Endocrine Society Meeting. Toronto, Canada, June [Abstract P1-367].

8. Muller CA, Uhl W, Printzen G, et al. Role of procalcitonin and granulocyte colony stimulating factor in the early of prediction infected necrosis in severe acute pancreatitis. Gut (2010) ; 46: 233-8.

9. Ammori BJ, Becker KL, Kite P, et al., Calcitonin precursors: early markers of gut barrier dysfunction in patients with acute pancreatitis. Pancreas (2003); 27: 239-43.

10. Sarbinowski R, Arvidsson S, Tylman M, et al. Plasma concentration of procalcitonin and systemic inflammatory response syndrome after colorectal surgery. Acta AnaesthesiolScand(2005); 49: 191-6.

11. Oruc N, Ozutemiz O, Osmanoglu N, Ilter T. Diagnostic value of serum procalcitonin in determining the activity of inflammatory bowel disease. Turk J Gastroenterol(2009); 20 (1): 9-12.

12. Oussalah A, Laurent V, Bruot $\mathrm{O}$, Guéant JL, Régent D, Bigard MA, Peyrin-Biroulet L. Additional benefit of procalcitonin to $\mathrm{C}$ reactive protein to assess disease activity and severity in Crohn's disease. Aliment PharmacolTher (2010); 32: 1135-1144.

13. Gasche, C., Lomer, M. C., Cavill, I. \& Weiss, G.Iron, anaemia, and inflammatory bowel diseases. Gut 53 (2004), 1190-1197.

14. Felker GM, Allen LA, Pocock SJ et al . Red cell distribution width as a novel prognostic marker in heart failure: data from the CHARM Program and the Duke Databank. J Am Coll Cardiol (2007); 50: 40-47.

15. Vermeire S, Stefan Schreiber, Sandborn WJ, Cecile Dubois, and PaulRutgeerts.Correlation Between the Crohn's Disease Activity and HarveyBradshaw Indices in Assessing Crohn's Disease Severity. Clinical Gastroenterology and hepatology (2010);8:357-363 
Dina Fathy. M., et al.,

16. Esmat Serag, Mohamed El Nady, Mohamed Elfekki et al . Epidemiological and clinical characteristics of inflammatory bowel diseases in Cairo, Egypt. World J Gastroenterol (2014).; 20(3): 814-821.

17. Matsuoka K, Kobayashi $\mathrm{T}$ and Ueno $\mathrm{F}$. Evidence-based clinical practice guidelines for inflammatory bowel disease Gastroenterol (2018). 53:305-353.

18. Ott $\mathrm{C}$ and Schölmerich J. Nat. Rev. Gastroenterol. Hepatol (2013). 10, 585-595.

19. Ipek Serkan, CemCekic, EmrahAlper et al . Can red cell distribution width be a marker of disease activity in ulcerative colitis? Int $\mathrm{J}$ Clin Exp Med (2015);8(8):13848-13853 www.ijcem.com /ISSN:19405901/IJCEM0010996.

20. Vermeire $S, G$ Van Assche and P Rutgeerts. LABORATORY MARKERS IN IBD: Useful, Magic, or Unnecessasry Toys? Gut (2006); 55:426-431.

21. Koido S, Ohkusa $\mathrm{T}$, Takakura $\mathrm{K}$ et al. Clinical significance of serum procalcitonin in patients with ulcerative colitis. World $\mathrm{J}$ Gastroenterol (2013); 19: 8335-8341.

22. Nishio E, Saruta M, Arihiro S, et al. The clinical benefit of procalcitonin to assess disease activity and severity in inflammatory bowel disease. Gastroenterology2016; 150: S995.

23. Chung SH, Lee HW, Kim SW et al. Usefulness of Measuring Serum Procalcitonin Levels in Patients with Inflammatory Bowel Disease. Gut Liver (2016); 10: 574-580.

24. $\mathrm{Ge} \mathrm{X}, \mathrm{Hu} \mathrm{D}, \mathrm{Cao} \mathrm{Y}$ et al. Procalcitonin in Crohn's disease with fever episodes, a variable to differentiate intra-abdominal abscess from disease flares. Int $\mathrm{J}$ Surg (2016); 36: 34-39.

25. Hosomi $\mathrm{S}$, Yamagami $\mathrm{H}$, Itani $\mathrm{S}$ et al. Sepsis markers soluble IL-2 receptor and soluble CD14 subtype as potential biomarkers for complete mucosal healing in patients with inflammatory bowel disease. $J$ Crohns Colitis (2017). 
تقييم نسبة البروكالسيتونين والحديد فى الام وتوزيع عرض خلايا الام الحمراء كعلامات بيولوجيه

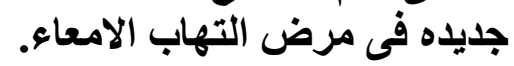

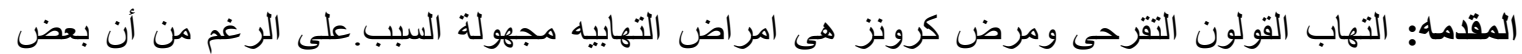

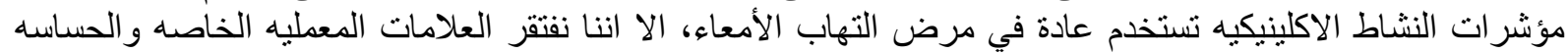

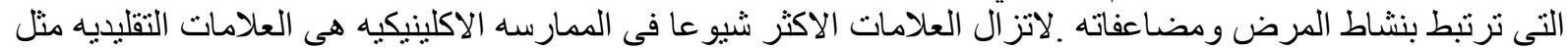

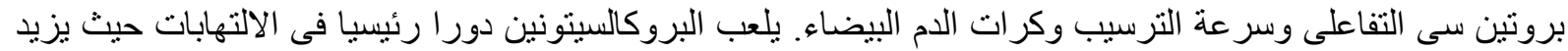

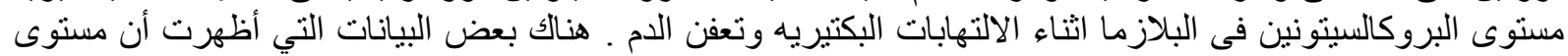

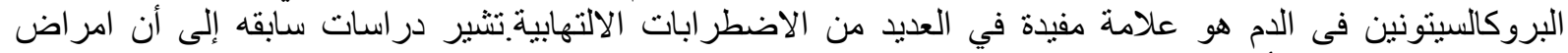

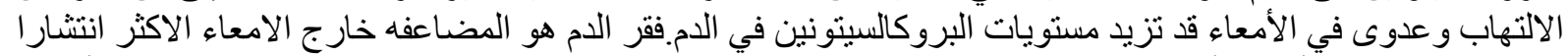

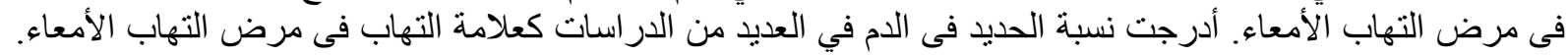

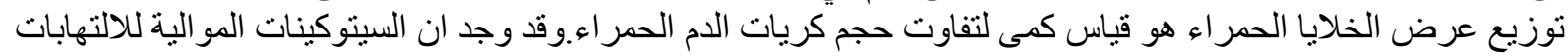

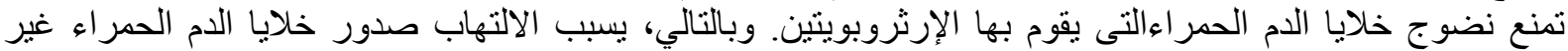
الناضجة في الدورة الدموية الطرفية، مما قد يؤدي إلى تفاوت الأنئ الكريات .

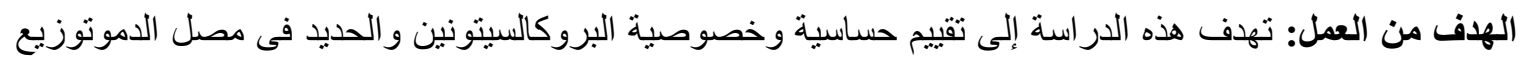

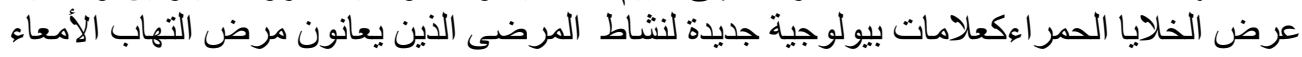

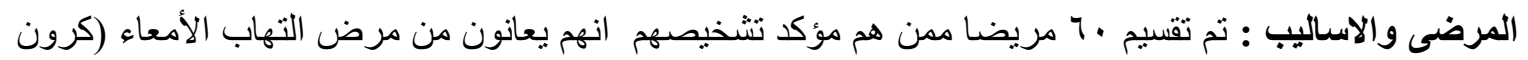

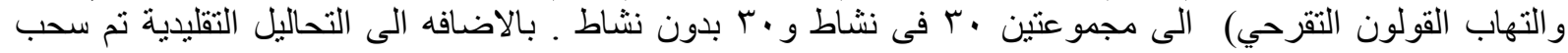

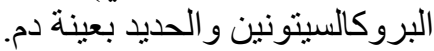

النتائج: وجدت النتائج فرق و اضح بين المجمو عنين فيما يخص نسبة ولئن الحديد في الدم حيث كان المتوسط اثناء النشاط و 26 mcg/dl بينما كان المتوسط في غير النشاط

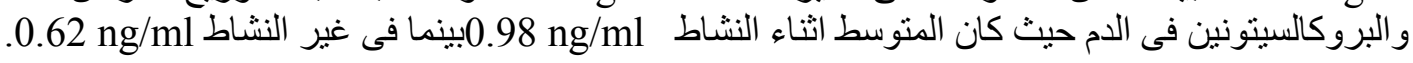

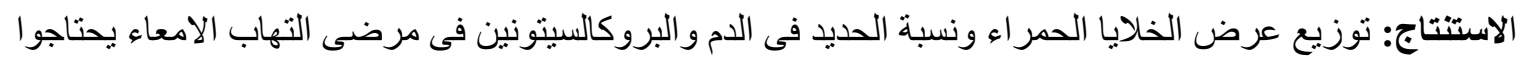

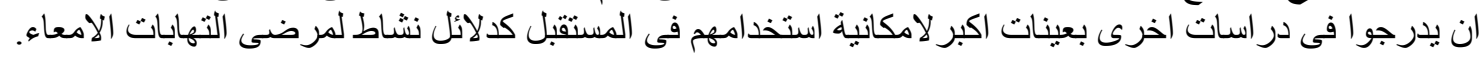

